\title{
床励振を受ける立位姿勢人体の筋張力に関する検討
}

\section{Study on Muscular Forces of Upright Human Subjected to Base Excitation}

\author{
○学 杉本 太志 (阪府大院) 正 伊藤 智博 (阪府大) 正 新谷 篤彦 (阪府大) \\ 正 中川智皓 (阪府大) 奥田 邦晴 (阪府大) 野中 紘士 (阪府大)
}

Taishi SUGIMOTO, Graduate School of Engineering, Osaka Pref. Univ., 1-1 Gakuen-cho, Naka-ku, Sakai-shi, Osaka Tomohiro ITO, Osaka Pref. Univ., Atsuhiko SHINTANI, Osaka Pref., Univ. Chihiro NAKAGAWA, Osaka Pref. Univ. Kuniharu OKUDA, Osaka Pref. Univ., Kouji NONAKA, Osaka Pref. Univ.

\section{1. 緒言}

高齢者の転倒は寝たきりや要介護状態につながる可能 性が非常に高く，これから向かう高齢化社会において転 倒予防は大きな社会的意義がある. 日常生活では摇れる 電車内や航空機内, 地震時など床励振を受ける状況が多 く存在しその状況下での転倒予防を検討することが必要 である.しかし，人体は非常に複雑であるため安定性維 持のメカニズムは未だ解明できていないところが多い.

そこで本研究では単純化した人体の解析モデルを構築 し，立位姿勢にある人体の床励振に対する応答と安定性 の基本的な現象について検討する.

\section{2. 簡易モデル化}

\section{$2 \cdot 1$ 剖体リンクモデル}

人体を矢状面の剛体リンクモデル (図 1)に簡略化する. $m_{i}, l_{i}, I_{i}, r_{i}, \phi_{i}, \theta_{i}(i=1, \ldots, 4)$ は, それぞれ各部位の 質量, 長さ, 慣性モーメント, 下側関節からの重心距離, 水 平方向からの角度, 鉛直方向上向きからの角度とし， $\varphi$ は足部の重心位置の水平方向からの角度とする。ここで, $i=1, \ldots, 4$ はそれぞれ足部, 下腿部, 大腿部, 上体部とする. $k_{j}, \quad c_{j}$ (j=ankle,knee,waist） は各関節にある回転ばね定 数, 回転減衰係数である.また, $a_{h e e l}, a_{t o e}$ は足裏踵側長 さ, 足裏つま先長さであり, $k_{\text {heel }}, k_{t o e}$ は足裏ばね定数踵 側, 足裏ばね定数つま先側とする ${ }^{(1)}$.

ただし，人体モデルは静的不安定であるため, 現実の 人体と同様，足首，膝，腰にそれぞれ反時計回りを正と する制御モーメント $M_{\text {ankle }}, M_{\text {knee }}, M_{\text {waist }}$ を与えること で姿勢の安定化制御を行う.

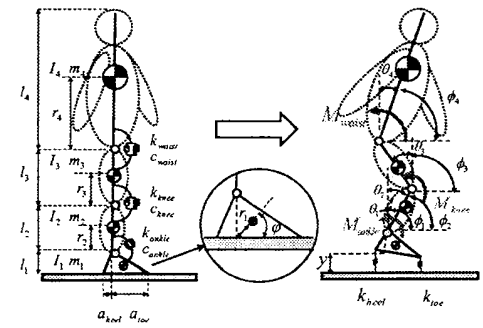

Fig. 1 Rigid link model of upright human

\section{$2 \cdot 2$ 運動方程式}

運動エネルギー $T$, 位置エネルギー $U$ をラグランジュ 方程式に代入しマトリクスの形にまとめ線形化すると次 式を得る。

$$
\begin{aligned}
& \dot{x}=A x+B u+C \ddot{z} \\
& x=\left[\begin{array}{llllllllll}
\theta_{1} & \theta_{2} & \theta_{3} & \theta_{4} & y & \dot{\theta}_{1} & \dot{\theta}_{2} & \dot{\theta}_{3} & \dot{\theta}_{4} & \dot{y}
\end{array}\right]^{T} \\
& u=\left[\begin{array}{lll}
M_{\text {ankle }} & M_{\text {knee }} & M_{\text {waist }}
\end{array}\right]^{T}
\end{aligned}
$$

ここで $U$ は制御モーメントを，艺は床に与える加速度べク トルを表す。

\section{3 筋骨格モデル}

前述したモーメントを用いて，図 2 のような 11 個の 筋群 (1. 大腿直筋， 2. 大殿筋，3. 八ムストリングス， 4. 広筋, 5. 大腿二頭筋, 6. 腓腹筋, 7. ヒラメ筋, 8. 前脛骨 笳, 9. 腸腰筋, 10 腹筋, 11 脊柱起立筋）の筋張力を推定 寸る. それぞれの筋に発生する筋張力を $F_{n}$, その最大值 を $F_{n}^{\text {max }}$ とし, 各々の筋に付着する関節のレバーアーム長 を $L_{j n}(n=1, \ldots, 11, j=$ ankle, knee, waist $)$ とすると，関節 回りのモーメントの釣合い関係より式 (4)を得る.

$$
\begin{gathered}
M_{j}=\sum_{n=1}^{11} F_{n} s_{j n} L_{j n} \\
E=\sum_{n=1}^{11}\left(\frac{F_{n}}{F_{n}^{\max }}\right)^{2}
\end{gathered}
$$

$s_{j n}$ は 1 か -1 の值を取る符号である. 式 (4) は不定問題 となるため, 式 (5) の下肢総エネルギー $E$ を評価関数と し, $E$ が最小となる最適解 $F_{n}$ を求める.

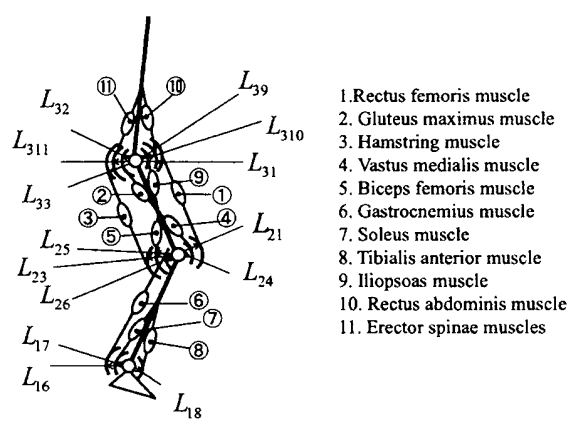

Fig. 2 Musculoskeletal model

3. 数値シミュレーション

図 3 に人がつまずく場合の相対的筋負担度（RML）を 示す．他の数値計算の詳細は当日に発表する.

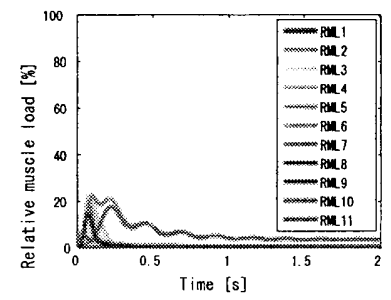

Fig. 3 Muscular forces at stumbling 文 献

(1) Kouchi, M., et al., Data base of size of Japanese human body 1997-98, AIST Digtal Human Research Center (2000). 